\title{
REVERSE AND INVERSE LOGISTIC MODELS FOR SOLID WASTE MANAGEMENT
}

\author{
L. Banguera ${ }^{1,2^{*}}$, J.M. Sepúlveda ${ }^{1}$, G. Fuertes ${ }^{1,3}$, R. Carrasco ${ }^{4} \&$ M. $\operatorname{Vargas}^{1}$
}

\section{ARTICLE INFO}

\section{Article details}

Submitted by authors

Accepted for publication 25 Oct 2017

Available online $\quad 13$ Dec 2017

Contact details

Corresponding author

leonardo.banguera@usach.cl

Author affiliations

1 Department of Industrial

Engineering, University of Santiago of Chile, Chile

2 Department of Industrial Engineering, University of Guayaquil, Ecuador

3 Facultad de Ingeniería, Ciencia y Tecnología, Universidad Bernardo O’Higgins, Santiago, Chile

4 Facultad de Administración y Economía, Universidad de Santiago de Chile, Santiago, Chile

\section{DOI}

http://dx.doi.org/10.7166/28-4-1701
This paper presents a literature review of different models of reverse and inverse logistics for solid waste management by using the content analysis method. The article has two parts. In the first part, the studies of diverse authors are discussed to define the activities or steps to be followed for a general model of reverse and inverse logistics. These authors establish four basic steps for managing solid waste (gatekeeping, collection, sorting, and disposal). The second part deals with exploratory studies, designs, methodologies, and proposed mathematical models to solve problems in inverse logistics, based on articles published between 2010 and 2016.

\section{OPSOMMING}

Hierdie artikel bied 'n oorsig van verskillende modelle van omgekeerde en inverse logistiek vir soliede rommelbestuur deur middel van die inhoud-analise metode. Die artikel het twee gedeeltes. Eerstens word die navorsing van verskeie outeurs bespreek met betrekking tot ' $n$ algemene model van omgekeerde en inverse logistiek. Hierdie outeurs vestig vier basiese stappe vir die bestuur van soliede rommel, naamlik hekwagting, versameling, sortering en wegmaking. Daarna word ondersoekende studies, ontwerpe, metodologieë en voorgestelde wiskundige modelle om die uitdagings in inverse logistiek aangespreek. Hierdie gedeelte van die artikel is gegrond op artikels wat tussen 2010 en 2016 gepubliseer is.

\section{INTRODUCTION}

Assertions made by Peña et al. [1] not only reveal their global concern for sustainable development, but have also been an influence in restating varied organisational aspects at a strategic level to reduce negative environmental impacts. Such impacts are present throughout the whole supply chain: from raw materials logistics management to the final products to be used by the customer. Therefore, supply chains should guarantee waste reduction in their goods production processes by devising environment-friendly production systems, managing secondary markets, and meeting environmental standards.

Likewise, management of materials or products returning to the supply chain also involve environmental impacts, posing their own challenge. To face this challenge, reverse logistics (RL) has become a strategy that comprises a series of operations concerning the proper assessment and allocation of solid waste (SW), once products have completed their life cycle. The terms 'RL' and 'inverse logistics' (IL) are synonyms; however, they are distinctive in that RL is applied to management models, while IL is the path through which assets and data regress in the traditional supply chain. In this article, instead of using the abbreviation 'RL/IL', the term 'IL' is regarded as equivalent to RL.

SW sustainable management involves a multi-criteria approach in which public and private organisations and the community make decisions, framed by time and space, according to their own dynamics and conditions [2]. 
In this sense, IL is closely linked with SW management through the most-often used industrial reprocessing options of remanufacturing and recycling. Remanufacturing is the process of repairing used products as brand new, while recycling involves the recovery of some of their components without keeping their previous identity. These reprocessing options of IL are directly linked to sustainable development, provided that society makes use of the whole value of the product [1].

Concerning the problems of IL network design, Flórez et al. [3] have mainly focused on waste management, materials recovery (recycling), product or spare-part recovery (remanufacturing or re-using), commercial return, and redistribution of recovered or new goods manufactured from waste material. In order to support waste management decision-making, authors such as Giuntini and Andel [4], Rogers and Tibben-Lembke [5], Schwartz [6], Stock [7], García [8], Ji [9], and Lambert et al. [10] have designed IL general models for SW management from which processes can be standardised.

To provide a state-of-the-art review of IL models for SW management, updated to 2016, this paper presents a review of theoretical exploratory studies of IL models and their application in different organisations.

In general, mixed integer linear programming (MILP) has been used to solve facility location problems [3]. However, recent papers have made advances using other approaches, such as probabilistic mixed integer programming models, genetic algorithms models, multiple regression models, and other mathematical modelling approaches. Other approaches to decision-making support have also been found, such as decision-making by fault modelling through cause-effect models; decisionmaking trial and evaluation laboratory (DEMATEL); root-cause system diagram; Delphi method; hierarchical regression analysis; hybrid methods using the analytic hierarchy process (AHP); and fuzzy sets models.

The topic is developed as follows: (1) introduction; (2) methodology; (3) inverse logistics network concepts development through time and SW management concepts for both direct and inverse flow; (4) literature review; and (5) research conclusions.

\section{METHODOLOGY}

The content analysis method was used in this literature review. For López [11], this method is a validated technique to analyse documents that allows the internal structure of the information to be discovered. Despite having positivist detractors, this method is validated as a useful method for qualitative research, and requires the application of rules similar to those of reliability and validity for credible research. A range of authors have used content analysis to carry out their research for example: a literature review on third-party logistics [12]; content analysis to review the perspectives of IL [13]; design of teaching and learning environments for training teachers in the use of information and communication technologies [14]; content analysis and sensograms to evaluate the sensory quality of genealogical groups of Arabica coffee [15]; identification and analysis of IL barriers using the fuzzy Delphi method and AHP [16]; and a bibliographical review using content analysis to publicise the latest advances in nanotechnology and its application to intelligent packaging development [17].

For the present study, the search process is limited to published literature, including books, congress proceedings, and other literature obtained from electronic sources. The current revision includes publications in scientific journals from 2010 to 2016, using the papers of Flórez et al. [3] as a stateof-the-art reference. The research process was carried out with scientific-technical bibliographical databases that included publications from portals such as Proquest, Scopus, Emeraldlnsight, Science Direct, and Inderscience. The following keywords were applied: IL models, SW management, integral supply chain, inverse supply chain. The articles analysed belong to the logistics management area (solution methods to IL problems in SW management), production, operations, and business logistics. The cited references in these articles were examined to determine additional sources of information.

The research covered the review of 5,200 publications, from which three books, three congress proceedings, and 68 journals made major contributions. The work areas are divided into the following: environmental sciences (11 per cent), production automation (seven per cent), operations 
research (35 per cent), computer science (11 per cent), industrial manufacturing ( 28 per cent), and other databases (eight per cent).

\section{CONCEPTUAL FRAMEWORK}

\subsection{Inverse logistics}

Every time people needed to move something from place to place, they figured out how, and how best, to do it. This challenge is still in force for IL. A short historical account of its evolution follows next.

According to Flórez et al. [3], IL arose in the 1970s as a new approach to recycling and re-using waste. IL studies processes for recovering end-of-life products to take advantage of their persisting value through their re-use, recycling, or remanufacturing, or proceeding to their appropriate disposal.

According to Mentzer et al. [18], in 1985 the Council of Logistics Management (CLM) defined logistics as that part of the supply chain process that plans, implements, and controls the efficient and effective flow and storage of goods, services, and related information from the point of origin to the point of consumption, with the purpose of meeting customers' requirements [19] [20] [21].

According to Stock [22], in 1992 the CLM published the first known definition of IL in relation to the role of logistics in dealing with recycling, waste disposal, and the management of dangerous materials. A broader perspective of IL includes everything related to the logistical activities carried out for incoming-raw-material reduction, recycling, substituting and re-using materials, and their final disposal. During the 1990s, the CLM published studies in which IL was recognised as a key concern of business and society.

Rogers and Tibben-Lembke [5] describe the IL process as one of planning, implementing, and efficiently controlling the flow cost of raw materials, in-process inventory, finished goods, and related information from the point of consumption to the point of origin, with the purpose of recovering the primary value of materials or disposing of them properly.

García [8] states that in 1998 the European Group on Reverse Logistics went further than the definition provided by Rogers and Tibben-Lembke [5], offering the following definition of IL: it is a process of planning, implementing, and controlling the flow of raw materials, in-process inventory, and finished goods from a point of use, manufacture, or distribution to a point of recovery or proper disposal. This definition is broader since it does not refer to a point of consumption, thus including even more flows, since one part does not necessarily return to its point of origin.

By 2003 the CLM modified its definition of logistics as follows: part of the process of the supply chain that plans, implements, and controls the efficient and effective forward / reverse flow and storage of goods and related information, from the point of origin to the point of consumption, with the purpose of meeting customers' requirements [8].

In this definition the interest in return flows (inverse flows) is clearly observed, since organisations started to compete in this field, in that IL let them manage the effective delivery of products or else integrate them again into the commercial channel, while always emphasising time and resources.

According to Govindan et al. [23], another definition to clarify this concept is the one given by the Reverse Logistic Executive Council: IL is the process of moving goods from their final typical destination to another point, in order to capture value that otherwise would not be available for the appropriate disposal of the products, thus introducing the concept of 'value recovery' of the components in the chain - one of the most important points about the concept at that time.

Hsu et al. [24] also define IL as any activity that involves management, processing, reduction, and disposal of products or waste, from production, packaging waste (boxes, pallets, drums, etc.), and/or goods used by the client up to the point of origin, for reprocessing or destruction. Wong et al. [25] indicate that IL implies the movement of products from the point of consumption, going through member channels to the point of origin, recovery, or reprocessing of the products. On the 
other hand, Kapetanopoulou and Tagaras [26] define IL as the set of processes in charge of receiving, evaluating, registering, and transforming or treating products returned by clients, with the purpose of converting them into environment-friendly or re-usable items for industry.

The origin of IL is explained from the moment that enterprises take several aspects into account, such as goods returned, recycling packaging and dangerous waste, treating obsolete products or seasonal inventories in any link of the supply chain, and being committed to effective and economical recovery [27] [28].

Lambert et al. [10] refer to the work of Fleischmann et al. [29], who subdivide IL into three main areas: distribution planning, inventory control, and production planning. This subdivision is derived from a survey that addressed the logistics of the industrial re-use of products and materials from the operations research perspective. Accordingly, $\mathrm{IL}$ is a discipline dealing with the management and optimisation of flows returning from the customer to the manufacturer.

From the definitions above, it is worth noting that logistics is here called 'inverse' because the flow of the product, information, and money is in the opposite direction - that is, from the customer to the point of origin or of reprocessing. This is the opposite of the traditional flow of the supply chain, which is from the point of origin (the enterprise or supplier) to the final point (the distributors or clients). Finally, it must be understood that the design and implementation of IL systems depends on the objectives established by the enterprises and their associated actors to generate value and to reduce costs with recovered products.

In summary, the definition of IL has changed over time, starting with a sense of inverse direction, going through an excessive emphasis on environmental aspects, returning to the original pillars of the concept, and finally, extending its scope of application. Figure 1 is a schematic representation of the flows in a supply chain, including the IL processes.

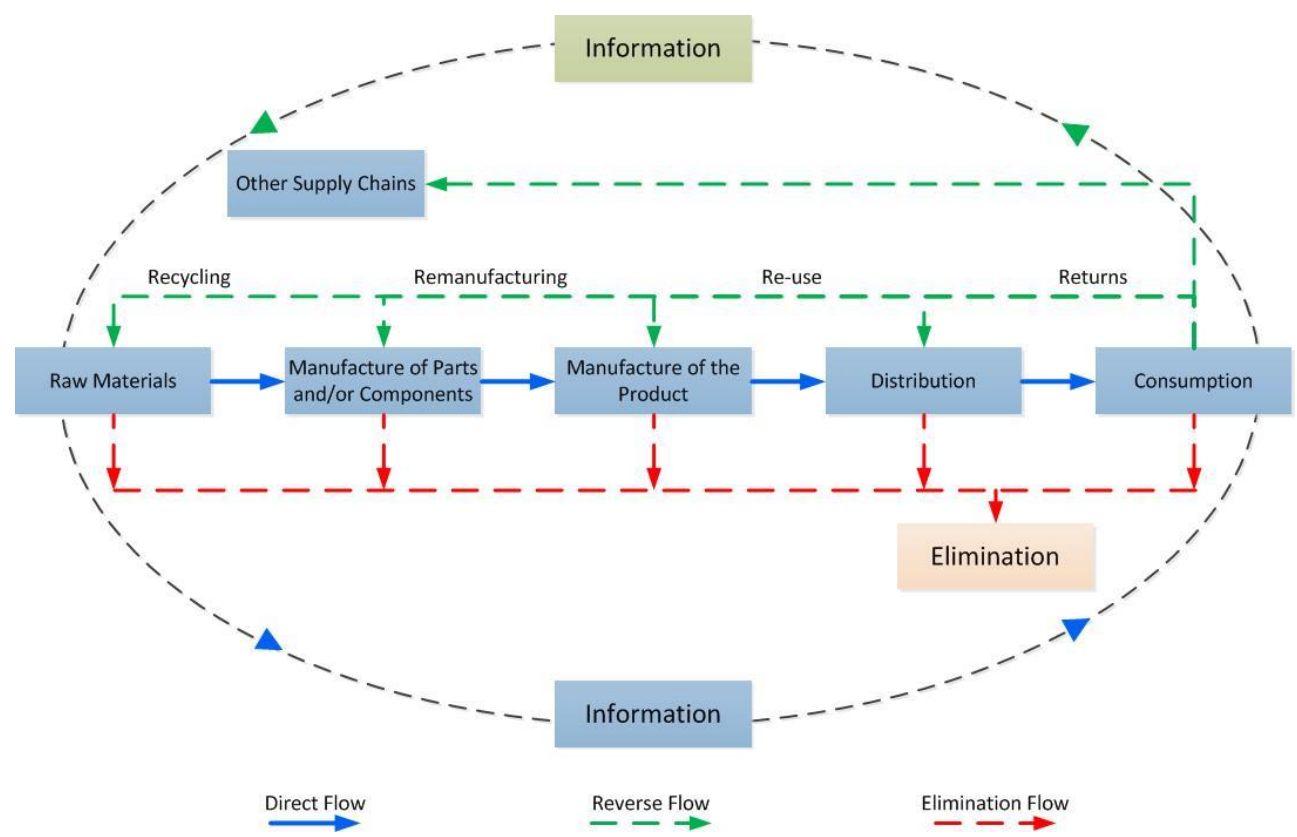

Figure 1: Schematic representation of flows in a supply chain, based on an elaboration by Chamorro and Rubio [30] (see online version for colour)

Even though logistics has always been an essential part of any economic activity, in recent decades there has been a growing interest in its development, to the point that an increasing number of enterprises are adopting it as a managerial tool because of the positive results yielded by its application. 


\subsection{Solid waste}

The Spanish Royal Academy [31] defines solid waste (SW) as the part or remaining portion of a whole that results from the breakdown or destruction of something, or useless material remaining after performing a job or operation.

For Christensen [32], SW is defined as any object or waste material produced after manufacturing, transformation, or use of consumer goods, that is abandoned after being used. These may or may not be susceptible of use or transformation for another direct or indirect use. The origin of the waste is the result of different daily activities - most of it generated in cities, specifically in residential areas where so-called urban solid waste (USW) is produced from activities in houses and public buildings such as schools and offices, together with building debris from repairs and demolition [33].

According to Rodríguez et al. [34], the generation of USW is overtaking its capacity to be recycled and re-used, thus producing an environmental problem. Landfills require greater areas every day for depositing waste. The problems related to USW collection and treatment are worsening as cities grow and their economies industrialise. USW is defined by Aglanu and Appiah [35] as waste generated in the urban community, coming from consumption processes and the development of human activities. USW is generated by residential, commercial, and institutional use, and by the cleaning of public spaces. USW also includes industrial and hospital waste - unless it is dangerous or toxic, in which case it must be handled differently, according to specific regulations.

\subsection{Integral management of SW}

For Velázquez [36], the integral management of waste is understood as the set of operations aimed at harnessing the materials and energy contained in waste in an environmentally safe way, and the responsible disposal of non-usable parts.

For Varón et al. [37], the integral management of waste refers to all of the actions related to its management, from its generation to its disposal. Contrary to the traditional view that all waste is disposed of when it has been generated, reducing waste at its origin is the first stage of intervention, thus decreasing the amount generated.

However, Couto and Hernández [38] define integral solid waste management (ISWM) as the socially articulated and interconnected set of regulations and actions of financial, planning, administrative, educational, monitoring, supervisory, and evaluative kind, for the management of waste, from generation to final disposal, in order to achieve environmental benefits, economic optimisation of its management, and social acceptance, responding to the needs and circumstances of each region. The variables comprising urban ISWM are shown in Figure 2.
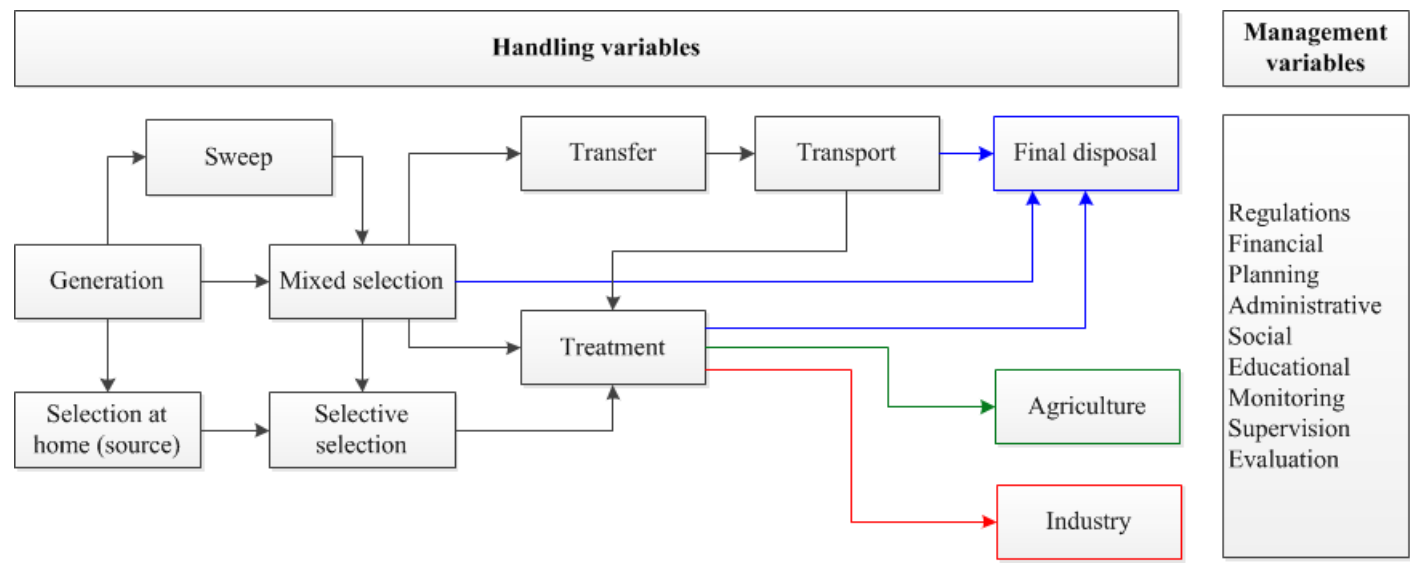

Figure 2: Variables involved in urban ISWM [38].

\subsection{Inverse logistics for the management of SW}

In Table 1 below, the general systems applied to IL are conceptualised chronologically, describing the general procedures used for solid waste management. 
Table 1: Stages of the general models of IL

\begin{tabular}{|c|c|c|c|c|c|c|c|}
\hline Author & 1 & 2 & 3 & 4 & 5 & 6 & 7 \\
\hline $\begin{array}{l}\text { Giuntini } \\
\text { and Andel } \\
\text { [4] }\end{array}$ & Recognition & Recovery & Review & Renewal & Removal & $\begin{array}{l}\text { Re- } \\
\text { engineering }\end{array}$ & \\
\hline $\begin{array}{l}\text { Rogers and } \\
\text { Tibben- } \\
\text { Lembke [5] }\end{array}$ & Gatekeeping & Compacting & Reverse & $\begin{array}{l}\text { Centralised return } \\
\text { centre (CRC) }\end{array}$ & $\begin{array}{l}\text { Remanufacture, } \\
\text { refurbishment, } \\
\text { and asset } \\
\text { recovery }\end{array}$ & $\begin{array}{l}\text { Negotiation } \\
\text { and financial } \\
\text { management }\end{array}$ & Outsourcing \\
\hline $\begin{array}{l}\text { Schwartz } \\
{[6]}\end{array}$ & Gatekeeping & Collection & Sorting & Disposal & & & \\
\hline Stock [7] & $\begin{array}{l}\text { Receiving, } \\
\text { unloading and } \\
\text { distribution }\end{array}$ & Processing & $\begin{array}{l}\text { Sorting, } \\
\text { inspection, and } \\
\text { routeing }\end{array}$ & $\begin{array}{l}\text { Repackaging, repair, } \\
\text { refurbishing or } \\
\text { remanufacturing, } \\
\text { and disposal }\end{array}$ & & & \\
\hline García [8] & Evaluation & $\begin{array}{l}\text { Reduction of } \\
\text { materials }\end{array}$ & $\begin{array}{l}\text { Reduction of } \\
\text { returns }\end{array}$ & Collection & Classification & Placement & $\begin{array}{l}\text { Measurement } \\
\text { and control }\end{array}$ \\
\hline Ji [9] & $\begin{array}{l}\text { Complaint } \\
\text { collected }\end{array}$ & Product return & $\begin{array}{l}\text { Production } \\
\text { inspection / Sortl } \\
\text { complaint } \\
\text { classification }\end{array}$ & $\begin{array}{l}\text { tIntegration } \\
\text { evaluation }\end{array}$ & Processing & Disposal & \\
\hline $\begin{array}{l}\text { Lambert et } \\
\text { al. [10] }\end{array}$ & $\begin{array}{l}t_{\text {system of }}^{\text {Coordinating }} \\
\text { returned goods }\end{array}$ & Gatekeeping & Collection & Sorting & $\begin{array}{l}\text { Processing or } \\
\text { treatment }\end{array}$ & $\begin{array}{l}\text { Integrated } \\
\text { information }\end{array}$ & $\begin{array}{l}\text { Disposal } \\
\text { system }\end{array}$ \\
\hline
\end{tabular}

In Table 1, the various authors establish a sequence of steps for IL management. The content analysis has allowed us to correlate the terminology, although the nomenclature used in the publications is different. For example, Giuntini and Andel [4] establish six steps: the first is 'recognition', for receiving a product returned from a client, giving two possible final destinations: 'renewal' or 'removal'; whereas Rogers and Tibben-Lembke [5] propose seven general steps for the management of IL, defining 'gatekeeping' as the entry of a product into the IL system, and establishing a detailed classification of the types of returned products. The model of Rogers and Tibben-Lembke [5] leaves to companies the final decision about the type of disposal that can be made out of the returned product.

Schwartz [6] proposes four stages for the management of IL: 'gatekeeping', 'collection', 'sorting', and 'disposal'. In the same way, Stock [7] also proposes four steps for the management of IL, subdividing 'gatekeeping' into 'receiving', 'unloading', and 'distribution'. In this case, 'collection' is included in 'gatekeeping'. For Stock [7], the second step is constituted by 'processing' the returned products; 'sorting' is further subdivided into 'inspection' and 'routeing'; and 'disposal' includes 'repackaging', 'repair', 'refurbishing or remanufacturing', and 'disposal'.

For Garcia [8], seven general steps are proposed. The first is a financial evaluation of the logistics system, through which a review of the process is made to optimise the return of the materials entering the IL system. Rogers and Tibben-Lembke [5] propose this same step in his model by introducing a CRC (centralised return centre) facility. For Ji [9] the process is divided into three major steps: the first is 'gatekeeping', subdivided into 'complaint collected' and 'product return'; the second is 'sorting', subdivided into 'production', 'inspection / sort', 'complaint', 'classification', 'integration', and 'evaluation'; and the final step is 'processing and disposal'.

Lambert et al. [10] establish seven general steps to coordinate the system of returned products; but they do not explicitly mention disposal, since it can occur at any stage of the process.

Authors such as Giuntini and Andel [4], Rogers and Tibben-Lembke [5], Schwartz [6], and Stock [7] propose an IL system that follows four main steps: gatekeeping (entry), collection, sorting, and disposal. Each activity performed in an IL system is interconnected with the others, and all are necessary for the successful implementation of the four steps [7].

The first step, gatekeeping, manages the entry to the system (recognition of product return (because it is defective or has finished its life cycle); Rogers and Tibben-Lembke [5] define it as deciding which products are authorised to enter the system. This step is essential for the successful management of the process and for cost control. The second step is the collection of the recognised 
products. The third step, sorting, is the detailed decision about the destination of each returned article. At that stage the company can decide what to do with the product - whether it is subject to inspection, testing, or other kind of handling. The fourth step, the final disposal of the product, gives two alternative destinations: (1) renewal or withdrawal from the return process (devolution to supplier and resale), or (2) final disposal in a dump [4].

IL manages the return of goods in the supply chain in the most effective and profitable way possible. It handles the recovery and recycling of packages, containers, and dangerous waste, as well as the return processes of inventory excess, clients' returns, obsolete products, and seasonal inventories. Other operational models for each of the purposes described above have been generated - mainly models seeking to minimise inventories (returns from clients, obsolete products, and so on).

\section{REVIEW OF THE LITERATURE WITH RESPECT TO INVERSE LOGISTICS}

The literature review at this stage corresponds with the period from January 2010 to January 2016. Through joint elaboration, each of the articles reviewed was classified according to the themes of its content. In this way, and by using a spreadsheet, the content of Table 2 was constructed, taking into account the different criteria of each of the authors. Most of the literature reviewed refers to exploratory theoretical studies of IL and of mixed integer linear programming (MILP) models to solve the logistical problems of returns.

Table 2: Review of the literature on IL

\begin{tabular}{lcl}
\hline Type & 2010-2016 & \multicolumn{1}{c}{ Issues identified } \\
\hline Exploratory & 15 & Exploratory theoretical study \\
\hline & 6 & Mixed integer linear programming \\
6 & Linear programming \\
4 & Mixed integer programming \\
3 & Genetic and heuristic algorithm \\
3 & Hybrid method using AHP and fuzzy modelling \\
& 2 & Multiple regression \\
1 & Non-linear integer programming model \\
1 & Causal-effect modelling by product fault analysis \\
1 & Multi-criteria decision-making by DEMATEL \\
& 1 & Diagram of causal systems \\
& 1 & Delphi method \\
1 & Analysis of hierarchical regression \\
& 1 & Network model \\
\hline
\end{tabular}

\subsection{Exploratory theoretical studies}

In relation to IL, Table 3 describes the main contributions of each of the 15 exploratory studies classified in Table 2. 
Table 3: Exploratory theoretical studies

\begin{tabular}{|c|c|}
\hline Authors & Fundamental aspects \\
\hline Gómez [39] & $\begin{array}{l}\text { IL conceptual approach; processes and applications at national and international } \\
\text { levels, including the relationship with the management of the green supply chain. }\end{array}$ \\
\hline Maheut [40] & $\begin{array}{l}\text { Flexibility on the operational decision-making in the context of planning and } \\
\text { management in the supply chains. }\end{array}$ \\
\hline Genchev et al. [41] & $\begin{array}{l}\text { IL state of development; potentiating the identification of its different areas in } \\
\text { various industries. }\end{array}$ \\
\hline Bernon et al. [42] & $\begin{array}{l}\text { Conceptual framework for the management of IL operations, to help professionals } \\
\text { and academics better comprehend key aspects in the management of IL. }\end{array}$ \\
\hline Gómez et al. [43] & $\begin{array}{l}\text { Analysis of the relation between IL and social responsibility as a strategy to } \\
\text { reduce impact on the environment, increase social benefits, and increase safety } \\
\text { of employees, clients and community through the study of enterprises in the } \\
\text { metropolitan zone of Antioquia, Colombia. }\end{array}$ \\
\hline Mihi et al. [44] & $\begin{array}{l}\text { Analysis of the implementation of IL practices in Spanish enterprises, studying the } \\
\text { current situation with the objective of examining those that are most significantly } \\
\text { influencing the management of IL activities. }\end{array}$ \\
\hline $\begin{array}{l}\text { Stindt and Sahamie } \\
\text { [45] }\end{array}$ & $\begin{array}{l}\text { Description and analysis of the main features in the planning of supply chains of } \\
\text { closed cycles in the process industry, with the purpose of determining the } \\
\text { evolution and difficulties of current research. }\end{array}$ \\
\hline Valenzo et al. [46] & $\begin{array}{l}\text { Theoretical exploration of the main IL publications that review successful cases in } \\
\text { the automobile industry, electronics, retail commerce, plastic recycling, and } \\
\text { improving business competitiveness in Mexico. }\end{array}$ \\
\hline Hall et al. [47] & $\begin{array}{l}\text { Discussion of the proper metrics for the IL process, through the analysis of } \\
\text { metrics used to monitor and control IL processes that allow enterprises to identify } \\
\text { deficiencies and choose the metrics that can be used to line up IL processes with } \\
\text { business goals. }\end{array}$ \\
\hline Moreira et al. [48] & $\begin{array}{l}\text { Two scenarios to evaluate IL in the cell phone industry by using the technique of } \\
\text { life cycle analysis. In a first scenario, batteries are the only components treated } \\
\text { in Brazil, whereas all other components are treated in Europe. In the second } \\
\text { scenario, a proposal is presented in which all treatments are conducted in Brazil. }\end{array}$ \\
\hline Govindan et al. [23] & $\begin{array}{l}\text { Review of literature of recent work on IL and the techniques used that allow a } \\
\text { framework of the past work to be drawn, and to define the future direction of IL. }\end{array}$ \\
\hline Guarnieri et al. [49] & $\begin{array}{l}\text { Identification of the main criteria for systematic methods with the purpose of } \\
\text { using the most adequate participation of third-party IL providers (3PRLP) }\end{array}$ \\
\hline Rezaei [50] & $\begin{array}{l}\text { Development of a reliable knowledge base through the accumulation of } \\
\text { knowledge from previous studies; a systematic review of the application of the } \\
\text { different methods of multi-criteria decision-making to different problems in IL. }\end{array}$ \\
\hline Agrawal et al. [51] & $\begin{array}{l}\text { Review of the literature on IL issues, with future directions of research based on } \\
\text { a gap analysis of what is currently in the literature. }\end{array}$ \\
\hline Bing et al. [52] & $\begin{array}{l}\text { Comparison between USW and municipal management practices in several } \\
\text { European countries in order to identify the features and key aspects of waste } \\
\text { management and IL. Review of literature on modelling USW logistics. }\end{array}$ \\
\hline
\end{tabular}

\subsection{Problems and methods in IL}

Regarding the type and method of solving IL problems, Table 4 below describes the main contributions of the remaining 31 articles classified in Table 2. These authors propose specific solutions to IL problems (returns, transport, inventories, types of suppliers, among others). 
Table 4: Models and methodologies applied to IL

Solving Method

\begin{tabular}{l} 
Type of problem \\
\hline Design of IL network to receive product returns by clients of electronic products commerce \\
[53]. \\
Design of an IL network for recycling plastics [54]. \\
Design of an IL network to meet the demands of the manufacturing and recycling centres with \\
minimum total cost under uncertainty conditions [55]. \\
Generation of better decisions at the operational level to receive and handle electrical and \\
electronic equipment waste (EEEW) at recycling facilities [56]. \\
Design of an IL network for electrical and electronic waste in Turkey [57]. \\
MILP for the design of an IL network, including the different actors participating in the \\
recovery system of vehicles at the end of their useful life [58]. \\
Analysis of the impact of IL in the ordering and amplification of inventory variance in a single- \\
echelon supply chain: proposition of a new ordering policy for dampening such amplification \\
[59]. \\
Reducing the number of plastic bottles disposed in dumpsters [60].
\end{tabular}

MILP

MILP

Probabilistic MILP

MILP

MILP

MILP

Differential equations model

Mathematical model

Identification of IL metrics with the purpose of monitoring the performance of IL processes along the value chain, specially the interaction between the supplier and the customer in complying with SW regulations [61].

Environmental implications for the supply chain in an IL environment [62].

IL network that participates in the management of USW where the financial management takes into account the latest legal requirements for SW management in Brazil [63].

The design of an optimal supply chain network plays a vital role in determining the carbon footprint. Therefore, the IL network should be designed so that it minimises cost and the total carbon footprint [64].

Problems with hybrid lot sizing (manufacturing and remanufacturing) where remanufactured products are treated as new ones, so that both types compete in order to meet demand [65].

Control and production planning optimisation of a generic type of integrated IL network that consists of a traditional forward production route, two alternative recovery routes (repair and remanufacturing), and a disposal route [66].

Design of the distribution network of IL for a third-party logistics service provider [67].

Importance of transportation costs and client satisfaction triggers researchers' interest in developing a flexible network design model with different supply lines [68].

Efficient management to handle medical waste, minimising maintenance cost [69].

Scheme for ecological transport with more complete logistic services to achieve minimized cost and environmental impact of IL [70].

Economic problem in IL, in relation to the size of the returned and recovered products [71].

Evaluation and selection of best contractor of IL [72].

Development of a new model to select suppliers in an IL system [73].

Identification and evaluation of the barriers to the implementation of IL in Brazil [16].

Capabilities of IL, and their influence in enterprises in achieving cost savings [74].

Perspectives of IL used for research development in sustainable development, theory of natural resources, and green innovation. These perspectives allow examination of the relationship between innovation, environmental performance, and economy, at the same time incorporates the institutional theory to verify how institutional pressures moderate such relationships [75].

Model of integer non-linear programming to determine the placement and number of plants and recycling stations, to minimise total cost [76].

Use of information technologies to support the IL process, obtaining improved process performance [77].

Identification of key issues that IL management professionals face, compared with existing research [78].
Method of partial minimal squares, models of structural equations

Mathematical model of a total cost function

Mathematical model

Mathematical model

Mixed integer

programming

Mixed integer programming with fuzzy optimisation

Mixed integer programming

Mixed integer programming model and memetic algorithm

Genetic algorithm

Genetic algorithm-based optimisation model

Variable metaheuristic algorithm

Hybrid method using the AHP and fuzzy technique

Multi-objective fuzzy

Fuzzy Delphi and AHP model

Multiple regression analysis

Hierarchical regression analysis

Non-linear integer programming model

Multiple regression analysis

Delphi mathematical model 


\begin{tabular}{|c|c|}
\hline Type of problem & Solving Method \\
\hline $\begin{array}{l}\text { Classification of alternatives to implement the IL process in the downstream photovoltaic } \\
\text { industry [79]. }\end{array}$ & Network model \\
\hline Case analysis of decision-making in IL for picking food products [80]. & $\begin{array}{l}\text { Fault analysis model } \\
\text { (cause-effect) }\end{array}$ \\
\hline Enhancement of performance of IL networks for product returns during their life cycle [81]. & DEMATEL \\
\hline $\begin{array}{l}\text { Systemic analysis of complex interaction of factors affecting IL in the pharmaceutical supply } \\
\text { chain [82]. }\end{array}$ & $\begin{array}{l}\text { Diagram of causal } \\
\text { system model }\end{array}$ \\
\hline
\end{tabular}

\section{CONCLUSION}

This article has reviewed the literature on different general models of IL for SW management. A variety of designs have been elaborated to solve different issues in $\mathrm{IL}$ - in particular, problems of returns in the supply chain and inventories. Reviewing the authors and topics cited by the authors in this paper, four major stages deserve attention: gatekeeping, collection, sorting, and disposal.

The exploratory study reviewed different current designs, methodologies and mathematical models for solving IL problems related to the complexities of product return, inventory management, and decision-making.

From the analysis of the 46 articles selected between January 2010 and January 2016, it is observed that 15 of them (32.6 per cent) correspond to exploratory studies of IL, and 31 (67.4 per cent) are applications to solve specific logistic problems, mainly to handle returns. Thus it can be stated that the MILP solution method is the one most often applied in this area.

This article has contributed to updating the state-of-the-art in IL research and practice by identifying work undertaken since 2010, and by offering guidance for future research directions.

This study can be used to support research and practice where IL is relevant. For instance, these models can be adapted to analyse governmental policies or private initiatives in emerging economies in promoting the reduction, recycling, and re-use of waste. With the aid of these models, new uses for end-of-life products and technology innovation scenarios can be tested.

Inverse logistics has become highly relevant in the scientific community for its ability to optimise the supply chain and logistics. However, there are issues that still represent an opportunity for further research, such as: a) how to manage uncertainty about the quantity and quality of products and materials recovered by enterprises; b) pricing models according to demand and the amount of waste generated; c) models for understanding consumer behaviour regarding the willingness to recycle; or d) models for understanding the economics of USW management. Ongoing work on the latter subject is carried out by the authors in a case study of used tyres collected at a network of tyre replacement centres in a large urban area. Used tyres can be recycled to produce pellets for rubber-made products, or to be used as fuel in industrial furnaces.

In relation to decision-making, industries may take into account the above process models and cases to attain a better understanding of the product lifecycle, paying attention to the environmental, economic, and social impact.

\section{CONFLICTS OF INTEREST}

The authors declare that there is no conflict of interest in the publication of this paper.

\section{ACKNOWLEDGEMENT}

The authors wish to thank DICYT University of Santiago de Chile, Grant 0615617SS, for support for this research. 


\section{REFERENCES}

[1] Peña, C., Torres, P., Vidal, C. \& Marmolejo, L. 2013. Reverse logistics and its relationship to the integral and sustainable solid waste management in productive sectors. Entramado, 9(1), pp. 226-238.

[2] Gasparatos, A., El-Haram, M. \& Horner, M. 2009. The argument against a reductionist approach for measuring sustainable development performance and the need for methodological pluralism. Accounting Forum, 33(3), pp. 245-256.

[3] Flórez, L., Toro, E. \& Granada, M. 2012. A network design for a reverse logistics: A review and a practical application. Ciencia e Ingeniería Neogranadina, 22(2), pp. 153-177.

[4] Giuntini, R. \& Andel, T. 1995. Master the six R's of reverse logistics. Transportation and Distribution, 36(3), pp. 93-98.

[5] Rogers, D. \& Tibben-Lembke, R. 1998. Going backwards: Reverse logistics trends and practices. Pittsburgh: Reverse Logistics Executive Council.

[6] Schwartz, B. 2000. Reverse logistics strengthens supply chains. Transportation \& distribution, 41(5), pp. 95-100.

[7] Stock, J.R. 2004. Product returns/reverse logistics in warehousing: Strategies, policies and programs. Oak Brook: Warehousing Education and Research Council.

[8] García, A. 2006. Recomendaciones táctico-operativas para implementar un programa de logística inversa: Estudio de caso en la industria del reciclaje. Edición electrónica gratuita.

[9] Ji, G.-J. 2008. Reverse logistics operation management based on virtual enterprises and complaint service management. Journal of Service Science and Management, 1(1), pp. 51-66.

[10] Lambert, S., Riopel, D. \& Abdul-Kader, W. 2011. A reverse logistics decisions conceptual framework. Computers \& Industrial Engineering, 61(3), pp. 561-581.

[11] López, F. 2002. El análisis de contenido como método de investigación. Revista de Educación, 4, pp. 167180.

[12] Marasco, A. 2008. Third-party logistics: A literature review. International Journal of Production Economics, 113(1), pp. 127-147.

[13] Pokharel, S. \& Mutha, A. 2009. Perspectives in reverse logistics: A review. Resources, Conservation and Recycling, 53(4), pp. 175-182.

[14] Cabero, J., Barroso, J. \& Llorente, M. 2010. El diseño de entornos personales de aprendizaje y la formación de profesores en TIC. Digital Education Review, (18), pp. 26-37.

[15] Sobreira, F.M., de Oliveira, A.C.B., Pereira, A.A., Sobreira, M.F.C. \& Sakyiama, N.S. 2015. Sensory quality of arabica coffee (Coffea arabica) genealogic groups using the sensogram and content analysis. Australian Journal of Crop Science, 9(6), pp. 486.

[16] Bouzon, M., Govindan, K., Rodriguez, C.M. \& Campos, L.M. 2016. Identification and analysis of reverse logistics barriers using fuzzy Delphi method and AHP. Resources, Conservation and Recycling, 108, pp. 182197.

[17] Fuertes, G., Soto, I., Carrasco, R., Vargas, M., Sabattin, J. \& Lagos, C. 2016. Intelligent packaging systems: Sensors and nanosensors to monitor food quality and safety. Journal of Sensors, 2016, pp. 1-8.

[18] Mentzer, J.T., DeWitt, W., Keebler, J.S., Min, S., Nix, N.W., Smith, C.D. \& Zacharia, Z.G. 2001. Defining supply chain management. Journal of Business Logistics, 22(2), pp. 1-25.

[19] Rutner, S.M. \& Langley, C.J. 2000. Logistics value: Definition, process and measurement. The International Journal of Logistics Management, 11(2), pp. 73-82.

[20] Rudberg, M. \& Olhager, J. 2003. Manufacturing networks and supply chains: An operations strategy perspective. Omega, 31(1), pp. 29-39.

[21] Mentzer, J.T., Min, S. \& Bobbitt, L.M. 2004. Toward a unified theory of logistics. International Journal of Physical Distribution \& Logistics Management, 34(8), pp. 606-627.

[22] Stock, J.R. 1992. Reverse logistics: White paper. Illinois, USA: Council of Logistics Management.

[23] Govindan, K., Soleimani, H. \& Kannan, D. 2015. Reverse logistics and closed-loop supply chain: A comprehensive review to explore the future. European Journal of Operational Research, 240(3), pp. 603626.

[24] Hsu, C.-C., Tan, K.-C. \& Zailani, S.H.M. 2015. Strategic orientations, sustainable supply chain initiatives, and reverse logistics: Empirical evidence from an emerging market. International Journal of Operations \& Production Management, 36(1), pp. 86-110.

[25] Wong, C.W.Y., Lai, K.-h., Lun, Y.H.V. \& Cheng, T.C.E. 2016. Closed loop supply chain, in Environmental Management, SpringerBriefs in Applied Sciences and Technology. Hong Kong: Springer International Publishing.

[26] Kapetanopoulou, P. \& Tagaras, G. 2011. Drivers and obstacles of product recovery activities in the Greek industry. International Journal of Operations \& Production Management, 31(2), pp. 148-166.

[27] Hsu, C.C., Tan, K.C., Zailani, S.H.M. \& Jayaraman, V. 2013. Supply chain drivers that foster the development of green initiatives in an emerging economy. International Journal of Operations \& Production Management, 33(6), pp. 656-688.

[28] de Leeuw, S., Grotenhuis, R. \& van Goor, A.R. 2013. Assessing complexity of supply chains: Evidence from wholesalers. International Journal of Operations \& Production Management, 33(8), pp. 960-980.

[29] Fleischmann, M., Bloemhof-Ruwaard, J.M., Dekker, R., van der Laan, E., van Nunen, J.A.E.E. \& van Wassenhove, L.N. 1997. Quantitative models for reverse logistics: A review. European Journal of Operational Research, 103(1), pp. 1-17. 
[30] Chamorro, A. \& Rubio, S. 2004. Los sistemas de distribución inversa para la recuperación de residuos: Su desarrollo en España. Distribución y consumo, 14(76), pp. 59-73.

[31] Real Academia Española. 2001. Diccionario de la lengua española [Dictionary of the Spanish Language] (22nd ed.). Madrid, Spain: Author.

[32] Christensen, T. 2011. Solid waste technology \& management. New Delhi: John Wiley \& Sons, Ltd.

[33] Soltani, A., Sadiq, R. \& Hewage, K. 2016. Selecting sustainable waste-to-energy technologies for municipal solid waste treatment: A game theory approach for group decision-making. Journal of Cleaner Production, 113, pp. 388-399.

[34] Rodríguez, M., Pico, G.B., González, M. \& Acoltzi, T. 2014. Efficient management of municipal solid waste: A mitigation strategy for climate change. Global Conference on Business \& Finance Proceedings, 9(2), pp. 880-887.

[35] Aglanu, L.M. \& Appiah, D.O. 2014. The Korle lagoon in distress: The stress of urban solid waste on water bodies in Accra, Ghana. International Journal of Innovation and Applied Studies, 7(2), pp. 717-728.

[36] Velázquez, A. 2008. The urban waste management in Hannover City: A successful model. Anales de Geografía de la Universidad Complutense, 28(1), pp. 163-177.

[37] Varón, K., Orejuela, J. \& Manyoma, P. 2015. Mathematical model for transfer station location of urban solid waste. Revista EIA, 12(23), pp. 61-70.

[38] Couto, I. \& Hernández, A. 2012. Participación y rendimiento de la iniciativa privada en la gestión integral de los residuos sólidos urbanos en la frontera México-Estados Unidos. Gestión y política pública, 21(1), pp. 215-261.

[39] Gómez, R. 2010. Inverse logistics: A process with environmental and productivity impacts. Producción + Limpia, 5(2), pp. 63-76.

[40] Maheut, J. 2011. Revisión de la literatura sobre la flexibilidad de decisión operacional. WPOM-Working Papers on Operations Management, 2(1), pp. 39-48.

[41] Genchev, S., Richey, R.G. \& Gabler, C. 2011. Evaluating reverse logistics programs: A suggested process formalization. The International Journal of Logistics Management, 22(2), pp. 242-263.

[42] Bernon, M., Rossi, S. \& Cullen, J. 2011. Retail reverse logistics: A call and grounding framework for research. International Journal of Physical Distribution \& Logistics Management, 41(5), pp. 484-510.

[43] Gómez, R., Correa, A. \& Vásquez, L.S. 2012. Reverse logistics, a social corporate responsibility approach/Logística inversa, un enfoque con responsabilidad social empresarial. Criterio Libre, 10(16), pp. 143-158.

[44] Mihi, A., Arias, D. \& García, V. 2012. Reverse logistics management in the Spanish firms: Towards practices of excellence. Universia Business Review, 1(33), pp. 70-82.

[45] Stindt, D. \& Sahamie, R. 2012. Review of research on closed loop supply chain management in the process industry. Flexible Services and Manufacturing Journal, 26(1-2), pp. 268-293.

[46] Valenzo, M., Galeana, E. \& Martínez, J. 2013. Exploration in reverse logistics business competitiveness in México. Global Conference on Business \& Finance Proceedings, 8(2), pp. 1603-1612.

[47] Hall, D., Huscroft, J., Hazen, B. \& Hanna, J. 2013. Reverse logistics goals, metrics, and challenges: Perspectives from industry. International Journal of Physical Distribution \& Logistics Management, 43(9), pp. 768-785.

[48] Moreira, D., Barreto, T. \& Regina, M. 2014. Life cycle assessment of cell phones in Brazil based on two reverse logistics scenarios. Production, 24(4), pp. 735-741.

[49] Guarnieri, P., Sobreiro, V.A., Nagano, M.S. \& Marques Serrano, A.L. 2015. The challenge of selecting and evaluating third-party reverse logistics providers in a multicriteria perspective: A Brazilian case. Journal of Cleaner Production, 96, pp. 209-219.

[50] Rezaei, J. 2015. A systematic review of multi-criteria decision-making applications in reverse logistics. Transportation Research Procedia, 10, pp. 766-776.

[51] Agrawal, S., Singh, R.K. \& Murtaza, Q. 2015. A literature review and perspectives in reverse logistics. Resources, Conservation and Recycling, 97, pp. 76-92.

[52] Bing, X., Bloemhof, J.M., Ramos, T.R.P., Barbosa-Povoa, A.P., Wong, C.Y. \& van der Vorst, J.G.A.J. 2016. Research challenges in municipal solid waste logistics management. Waste Management (New York, USA), 48, pp. 584-592.

[53] XiaoYan, Q., Yong, H., Qinli, D. \& Stokes, P. 2012. Reverse logistics network design model based on ecommerce. International Journal of Organizational Analysis, 20(2), pp. 251-261.

[54] Bing, X., Bloemhof-Ruwaard, J.M. \& van der Vorst, J.G.A.J. 2012. Sustainable reverse logistics network design for household plastic waste. Flexible Services and Manufacturing Journal, 26(1-2), pp. 119-142.

[55] Roghanian, E. \& Pazhoheshfar, P. 2014. An optimization model for reverse logistics network under stochastic environment by using genetic algorithm. Journal of Manufacturing Systems, 33(3), pp. 348-356.

[56] Capraz, O., Polat, O. \& Gungor, A. 2015. Planning of waste electrical and electronic equipment (WEEE) recycling facilities: MILP modelling and case study investigation. Flexible Services and Manufacturing Journal, 27(4), pp. 479-508.

[57] Kilic, H.S., Cebeci, U. \& Ayhan, M.B. 2015. Reverse logistics system design for the waste of electrical and electronic equipment (WEEE) in Turkey. Resources, Conservation and Recycling, 95, pp. 120-132.

[58] Demirel, E., Demirel, N. \& Gökçen, H. 2016. A mixed integer linear programming model to optimize reverse logistics activities of end-of-life vehicles in Turkey. Journal of Cleaner Production, 112, pp. 21012113.

[59] Turrisi, M., Bruccoleri, M. \& Cannella, S. 2013. Impact of reverse logistics on supply chain performance. International Journal of Physical Distribution \& Logistics Management, 43(7), pp. 564-585. 
[60] Matar, N., Jaber, M.Y. \& Searcy, C. 2014. A reverse logistics inventory model for plastic bottles. The International Journal of Logistics Management, 25(2), pp. 315-333.

[61] Hazen, B.T., Overstreet, R.E., Hall, D.J., Huscroft, J.R. \& Hanna, J.B. 2015. Antecedents to and outcomes of reverse logistics metrics. Industrial Marketing Management, 46, pp. 160-170.

[62] Bazan, E., Jaber, M.Y. \& El Saadany, A.M.A. 2015. Carbon emissions and energy effects on manufacturing remanufacturing inventory models. Computers \& Industrial Engineering, 88, pp. 307-316.

[63] Ferri, G.L., Diniz Chaves, G.d.L. \& Mattos Ribeiro, G. 2015. Reverse logistics network for municipal solid waste management: The inclusion of waste pickers as a Brazilian legal requirement. Waste Management, 40, pp. 173-191.

[64] Choudhary, A., Sarkar, S., Settur, S. \& Tiwari, M.K. 2015. A carbon market sensitive optimization model for integrated forward-reverse logistics. International Journal of Production Economics, 164, pp. 433-444.

[65] Belluco, P., Alem, D., Santos, M., Lage, M. \& Moreno, A. 2015. Hybrid manufacturing and remanufacturing lot-sizing problem with stochastic demand, return, and setup costs. The International Journal of Advanced Manufacturing Technology, 82(5-8), pp. 1241-1257.

[66] Niknejad, A. \& Petrovic, D. 2014. Optimisation of integrated reverse logistics networks with different product recovery routes. European Journal of Operational Research, 238(1), pp. 143-154.

[67] Suyabatmaz, A.Ç., Altekin, F.T. \& Şahin, G. 2014. Hybrid simulation-analytical modeling approaches for the reverse logistics network design of a third-party logistics provider. Computers \& Industrial Engineering, 70, pp. 74-89.

[68] Yadegari, E., Najmi, H., Ghomi-Avili, M. \& Zandieh, M. 2015. A flexible integrated forward/reverse logistics model with random path-based memetic algorithm. Iranian Journal of Management Studies (IJMS), 8(2), pp. 287-313.

[69] Hejrani, S. \& Ko, H.S. 2013. A reverse logistics model for medical waste management. IIE Annual Conference Proceedings, pp. 97-105.

[70] Lin, C., Choy, K.L., Ho, G.T.S. \& Ng, T.W. 2014. A genetic algorithm-based optimization model for supporting green transportation operations. Expert Systems with Applications, 41(7), pp. 3284-3296.

[71] Sifaleras, A., Konstantaras, I. \& Mladenović, N. 2015. Variable neighborhood search for the economic lot sizing problem with product returns and recovery. International Journal of Production Economics, 160, pp. 133-143.

[72] Senthil, S., Srirangacharyulu, B. \& Ramesh, A. 2014. A robust hybrid multi-criteria decision making methodology for contractor evaluation and selection in third-party reverse logistics. Expert Systems with Applications, 41(1), pp. 50-58.

[73] Moghaddam, K. 2015. Fuzzy multi-objective model for supplier selection and order allocation in reverse logistics systems under supply and demand uncertainty. Expert Systems with Applications, 42(15-16), pp. 6237-6254.

[74] Jack, E., Powers, T. \& Skinner, L. 2010. Reverse logistics capabilities: Antecedents and cost savings. International Journal of Physical Distribution \& Logistics Management, 40(3), pp. 228-246.

[75] Huang, Y.-C. \& Yang, M.-L. 2014. Reverse logistics innovation, institutional pressures and performance. Management Research Review, 37(7), pp. 615-641.

[76] Zhou, X. \& Zhou, Y. 2015. Designing a multi-echelon reverse logistics operation and network: A case study of office paper in Beijing. Resources, Conservation and Recycling, 100, pp. 58-69.

[77] Huscroft, J., Hazen, B., Hall, D. \& Hanna, J. 2013. Task-technology fit for reverse logistics performance. The International Journal of Logistics Management, 24(2), pp. 230-246.

[78] Huscroft, J., Hazen, B., Hall, D., Skipper, J. \& Hanna, J. 2013. Reverse logistics: Past research, current management issues, and future directions. The International Journal of Logistics Management, 24(3), pp. 304-327.

[79] Hsueh, J.-T. \& Lin, C.-Y. 2014. Constructing a network model to rank the optimal strategy for implementing the sorting process in reverse logistics: Case study of photovoltaic industry. Clean Technologies and Environmental Policy, 17(1), pp. 155-174.

[80] Kumar, S. 2014. A knowledge based reliability engineering approach to manage product safety and recalls. Expert Systems with Applications, 41(11), pp. 5323-5339.

[81] Shaik, M.N. \& Abdul-Kader, W. 2014. Comprehensive performance measurement and causal-effect decision making model for reverse logistics enterprise. Computers \& Industrial Engineering, 68, pp. 87103.

[82] Narayana, S., Elias, A. \& Pati, R. 2014. Reverse logistics in the pharmaceuticals industry: A systemic analysis. The International Journal of Logistics Management, 25(2), pp. 379-398. 